\title{
VOLTAMMETRY OF TETRA-ALKYL AMMONIUM SALTS AT PLATINUM IN SULPHUR DIOXIDE SOLUTION: OXIDATION OF THE HALIDES*
}

\author{
M. SAKuma and P. J. Elving \\ University of Michigan, Ann Arbor, Michigan, U.S.A.
}

\begin{abstract}
Abotract-The polarographic or voltammetric behaviour of a selected group of tetra-alkyl ammonium halides and related compounds in liquid sulphur dioxide was investigated, using a stationary disk platinum indicating micro-electrode and a silver/silver-bromide reference electrode with compensation for the $I R$ drop of the solution. The electrochemical oxidation-reduction patterns are characteristic of the natures of the cation and anion composing the compound.

Generally, good reproducible polarograms are obtained. The anodic patterns indicate that the oxidation of each halogen ion can occur in multiple stages, although the bromides generally show only a single anodic wave. The order of ease of electrolytic oxidation in sulphur dioxide is iodide (easiest), bromide and chloride.

Sulphur dioxide solutions of the tetra-alkyl ammonium salts show a characteristic cathodic discharge potential in the range of -0.3 to $-0.6 \mathrm{~V}$ vs $\mathrm{Ag} / \mathrm{AgBr}$. If the sulphur dioxide is insufficiently purified, two cathodic waves appear, which are apparently due to a non-condensable gas other than oxygen, sulphur trioxide or water.
\end{abstract}

Résumé-Au moyen d'une micro-électrode à disque fixe de Pt et d'une électrode de référence AgAgBr, compensant par ailleurs les chutes ohmiques des solutions, l'on étude les comportements voltamétrique et polarographique de tout un groupe d'halogénures de tétra-alkyl ammonium et certains dérivés, dans $\mathrm{SO}_{2}$ liquide comme solvant. Les caractères électrochimiques de l'oxydation et de la réduction sont spécifiques des natures du cation et defanion du composé. Les polarogrammes sont généralement reproductibles. Les branches anodiques indiquent que l'oxydation d'un ion halogéné s'effectue en plusieurs stades; les bromures, toutefois, ne manifestent qu'une vague anodique. L'ordre de facilité décroissante de l'oxydation électrolytique dans $\mathrm{SO}_{2}$ liquide est $\mathrm{I}^{-}, \mathrm{Br}^{-}, \mathrm{Cl}^{-}$. Une tension caractéristique de décharge cathodique se manifeste pour chaque sel, entre $-0,3$ et $-0,6 \mathrm{~V}$ (vs $\mathrm{Ag}-\mathrm{AgBr}$ ). Si le solvant ( $\mathrm{SO}_{2}$ liq.) n'est pas suffisamment pur, deux vagues cathodiques apparaissent, probablement à cause de la libération d'un gaz autre que $\mathrm{O}_{2}, \mathrm{SO}_{3}, \mathrm{H}_{2} \mathrm{O}$.

Zasammenfassung - Es wurde das polarographische oder voltametrische Verhalten einer ausgewählten Gruppe von Tetra-Alkyl-Ammoniumhalogeniden und verwandter Verbindungen in flüssigem Schwefeldioxyd untersucht unter Verwendung einer stationären Pt-Scheiben-Indikator-Mikroelektrode und einer Silber/Silber-Bromid-Referenzelektrode, wobei für den Spannungsabfall in der Lösung korrigiert wurde. Das Bild der Oxydation/Reduktionskurve ist charakteristisch für die Natur des Kations und des Anions, aus dem sich die Verbindung zusammensetzt.

Im allgemeinen wurden gut reproduzierbare Polarogramme erhalten. Die anodischen Kurven zeigen, dass die Oxydation jedes Halogenions in mehreren Stufen stattfinden kann, obschon die Bromide im allgemeinen nur eine einzige anodische Welle zeigen. Die Reihenfolge der Leichtigkeit der elektrolytischen Oxydation in Schwefeloxyd ist Jodid (am leichtesten), Bromid und Chlorid.

Lösungen der Tetra-Alkyl-Ammonium-Salze in Schwefeldioxyd zeigen charakteristische kathodische Abscheidungspotentiale in der Gegend von 0,3-0,6 V gegen Ag/AgBr. Wenn das Schwefeldioxyd ungenügend gereinigt ist, treten zwei kathodische Wellen auf, welche augenschein'ich einem nicht kondensierbarem Gas, jedoch nicht als Sauerstoff, Schwefeltrioxyd oder Wasser, zuzuschreiben sind.

\section{INTRODUCTION}

Although the feasibility of voltammetry and polarography in the non-protonic solvent, liquid sulphur dioxide, has been demonstrated, ${ }^{1,2}$ the fundamental experimental requirements for successful voltammetry of (a) a reliably responsive indicating

* Manuscript received 18 June 1964. 
electrode, (b) a totally non-polarizable reference electrode, and (c) the availability of soluble electrolytes with relatively high decomposition potentials to serve as background electrolytes and provide solutions with appreciable conductivity, have been only partially satisfied.

\section{Previous work}

The dropping mercury electrode (dme) is inferior as an indicating electrode for voltammetry in liquid sulphur dioxide to the cylindrical platinum electrode (cpe), because of its poor reproducibility, which is ascribed to reaction of the mercury with solutes. ${ }^{1-3}$ The cpe usually exhibits a current peak, which seriously limits its usefulness. Peak potentials and half-height potentials for the reduction of cations are reproducible, but the corresponding currents are somewhat variable. "Renewal" of the cpe by audio-frequency alternating current is necessary.

The behaviour of the cylindrical gold electrode, which was used for a few voltammetric studies, is generally similar to that of the cpe with its reproducibility being not quite as good. ${ }^{3}$

Cruse $^{4}$ reported the potential of silver/silver-halide electrodes, as indicated by potentiometric measurement, to be quite stable in liquid sulphur dioxide. These electrodes have also been found to be reliable reference electrodes for voltammetry. ${ }^{1-8,5}$

No solutes fully satisfactory as background electrolytes in liquid sulphur dioxide have yet been found, although voltammetry of a series of compounds at the cpe $\mathbf{e}^{3,5}$ allowed them to be divided into two groups, viz those showing high resistance and those showing low resistance. Consequently, there still exists as characteristic features of voltammetry in liquid sulphur dioxide the absence of a background electrolyte and a high solution resistance.

As depolarizers, the behaviour of triphenylchloromethane at the cpe was studied in detail and the reduction of triphenylmethyl free radical discussed. ${ }^{2}$ Other compounds previously studied at the cpe include some quaternary ammonium halides, some alkali metal halides and thiocyanates, and several other inorganic and organic compounds, ${ }^{1-3,5}$ these compounds generally exhibit only peak or discharge currents, except that two variable cathodic waves were exhibited in some runs on the tetraalkyl ammonium bromides.

\section{Objective of present study}

The primary purposes of the present work were (a) to develop a more useful and reliable technique for voltammetry in liquid sulphur dioxide with the platinum electrode and (b) to study systematically a large group of related compounds.

The electrode system was modified to improve the reproducibility of polarograms by depressing the polarization of the reference electrode. In addition, a means was introduced of compensating automatically for the $I R$ drop due to the high solution resistance by means of a three-electrode system.

The modified electrode system involving a disk indicating platinum microelectrode in place of the cylindrical platinum electrode was then applied to the investigation of a large series of tetra-alkyl ammonium halides, in which the identities of both quaternary ion and halide were varied, and of a large number of related compounds. 


\section{EXPERIMENTAL}

\section{Chemicals}

Anhydrous grade sulphur dioxide (Matheson; stated purity: 99.98 per cent) was treated to remove $\mathrm{H}_{2} \mathrm{O}, \mathrm{SO}_{3}$ and non-condensable gases essentially as previously described. 1

The following were Eastman Kodak chemicals: tetra-methylammonium chloride and bromide (recrystallized from ethanol); tetra-ethylammonium chloride, bromide (recrystallized from ethanol), iodide (recrystallized from acetone-ethyl acetate) and perchlorate; tetra-n-butylammonium bromide (recrystallized from ethyl acetate), iodide (recrystallized from acetone-ethyl acetate), nitrate and picrate; and 1-ethylpyridinium bromide. Coleman \& Bell $n-\mathrm{Bu}_{4} \mathrm{NBr}$ was also used.

Reagent grade potassium chloride (J. T. Baker), potassium bromide (Allied Chemical), potassium iodide (Merck), potassium chlorate, lithium perchlorate (G. Frederick Smith Chemical), iodine (resublimed), bromine (Mallinckrodt Chemical), and tri-n-butyl amine were also used.

\section{Apparatus}

The disk platinum electrode cell (Fig. 1) was constructed from a 100-ml Pyrex graduated cylinder by closing the lower end with a flat bottom and sealing a 55/50

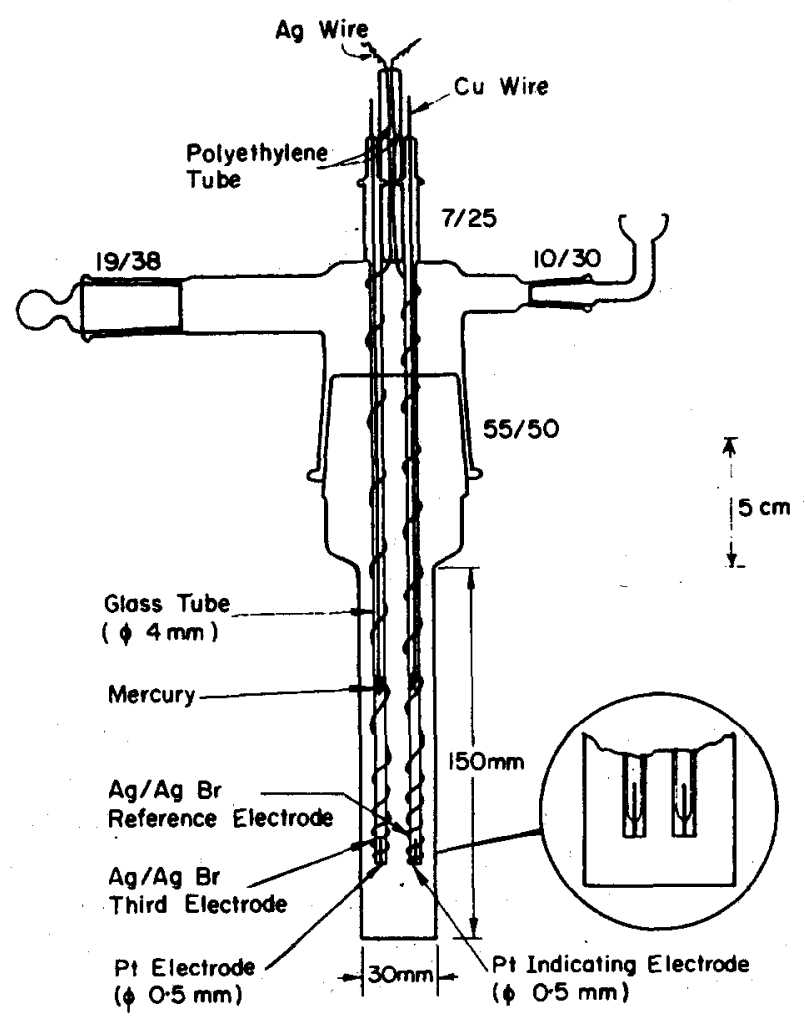

FiG. 1. Cell assembly involving a three-electrode arrangement based on the disk platinun indicating electrode and the $\mathrm{Ag} / \mathrm{AgBr}$ reference electrode. 
inner joint to the upper end; the engraved volume scale was calibrated. One side tube on the capping 55/50 outer joint was closed by a stopper; another was connected via a ball joint to the vacuum line system for introducing sulphur dioxide.

The disk electrode $(0.5 \mathrm{~mm}$ dia.) was formed by sealing a platinum wire $0.5 \mathrm{~mm}$ dia. and about $15 \mathrm{~mm}$ long) into the bottom of a glass tube ( $4 \mathrm{~mm}$ outer dia.) and then polishing both platinum and glass tube with sand paper (No. 1/2 and 4/0), emery paper (No. 4/0) and, finally, a whetstone to expose only the cross-section of platinum wire at the bottom of the glass tube. The indicating electrode was installed through a ground joint in the cell cap together with a second identically-similar disk platinum electrode; the two platinum electrodes were short-circuited between successive measurements, as subsequently discussed.

The $\mathrm{Ag} / \mathrm{AgBr}$ reference electrode, which was coiled around the bottom of the glass tube of the indicating electrode, was a silver wire helix $(0.4 \mathrm{~mm} \mathrm{dia}$. and $150 \mathrm{~mm}$ long), upon whose surface $\mathrm{AgBr}$ was deposited electrolytically; ${ }^{6}$ the ratio of the area of the reference electrode to that of the indicating electrode was several hundred. A similar $\mathrm{Ag} / \mathrm{AgBr}$ helix $(0.4 \mathrm{~mm}$ dia. and $120 \mathrm{~mm}$ long), which served as a third electrode for IR compensation, ${ }^{7,8}$ was coiled on the opposite platinum electrode glass tube. A sufficiently long length of silver wire was left in each case to allow its being brought out through a ground joint glass tube in the cell cap; the wires were insulated from each other by polyethylene tubes and the cap was made vacuum-tight by applying silicone lubricant (Dow Corning) to each ground joint, and filling the space in each tube with Apiezon wax.

The same set of electrodes was used in all of the experiments described.

\section{Operation}

The gas-handling (vacuum-line) system for purifying, charging into the cell and venting sulphur dioxide was essentially the same as that previously described. ${ }^{1}$

The cell was immersed in a 2-propanol-Dry-Ice bath, which was controlled to $-20 \pm 0.5^{\circ}$ by adding a small piece of Dry Ice before each run. Particular attention was paid to preventing any vibration of the cell during a run, which was started after the bubbling of $\mathrm{CO}_{2}$ in the bath ceased.

Current potential curves were recorded by a Sargent Model FS polarograph, which was modified by a change of gears and motor to simulate the performance of a Model XV polarograph. The Sargent Model A IR compensator was used with the three electrodes indicated. Solution resistance was measured with a Jones-type conductivity bridge.

\section{Procedures}

The cell containing the solid sample to be tested and a stirring bar (a piece of iron nail enclosed in glass of external dimensions $4 \times 17 \mathrm{~mm}$ ) was attached to the gas handling system and evacuated to about $10^{-5} \mathrm{~mm} \mathrm{Hg}$ with a mercury diffusion pump. The desired amount of sulphur dioxide, previously boiled for around $30 \mathrm{~min}$ to remove a slight amount of non-condensable gas and other possible impurities, was distilled directly into the cell and stirred with an outer magnet to dissolve the solute; the cell was brought to operating temperature, and electrical measurements made. The interval between successive runs on the same solution was usually $10 \mathrm{~min}$, during which period the indicating and opposite platinum electrodes were short-circuited in the attempt to renew the indicating electrode. 
The effectiveness of the latter short-circuit procedure was not conclusively ascertained during orientative runs on potassium bromide solution; however, the behaviour was more reproducible if the short-circuit procedure was used. Since the procedure should theoretically be effective and since fairly good reproducible polarograms were obtained on application of the procedure, it was used in all subsequent runs.

In order to vary concentration by dilution of the initial solution, additional sulphur dioxide was distilled into the cell. For the addition of more solute or other solutes, nitrogen was introduced at slightly greater than atmospheric pressure through the 10/30 arm and the cell was momentarily opened to introduce through the $19 / 38$ arm the solute contained in very small glass weighing bottles. The cell was carefully warmed by removing the cold bath, and sulphur dioxide gas and nitrogen gas at an elevated pressure were flushed out by opening momentarily the 10/30 arm. The cell was then brought back to temperature and measurements made.

\section{RESULTS AND DISCUSSION}

The experimental results are summarized in Tables 1 and 2 . All potentials cited are $v s$ the $\mathrm{Ag} / \mathrm{AgBr}$ electrode and are corrected for $I R$ drop. No "indifferent" electrolyte was added except for a few runs in which potassium bromide was tried as background electrolyte.

Generally, polarograms obtained by the three-electrode system involving the disk platinum microelectrode and an $I R$ drop compensator were quite satisfactory. Waves were usually well-defined and showed a limiting current plateau, which was sometimes followed by a decline in the current. The cathodic current peaks previously observed ${ }^{2}$ with the cylindrical platinum electrode were not seen, except in the cases of mixtures of (a) bromine and $\mathrm{KBr}$, and (b) $n-\mathrm{Bu}_{4} \mathrm{NBr}, \mathrm{KBr}$, and $\mathrm{H}_{2} \mathrm{O}$, where a minor peak appeared. The difference seems to be largely due to decreased polarizability of the reference electrode, which would result from the much larger ratio of reference electrode to indicating electrode area and the use of the $I R$ drop compensator. (The electrode area ratio in the cylindrical electrode system ${ }^{1,2}$ was only about 30 -fold, compared to one of several hundred in the present system.) Rates of polarization in the present study were comparable to those previously used., ${ }^{1,2}$

The characteristics of the polarograms in repeated runs on the same solution or on separately prepared solutions were fairly reproducible, except that variable cathodic waves due to a non-condensable gas were observed in some runs on solutions of $\mathrm{Et}_{4} \mathrm{NBr}$ and $n-\mathrm{Bu}_{4} \mathrm{NBr}$ ( $c f$ subsequent discussion).

The half-height potentials of the waves (including the cathodic waves jus: mentioned) were reproducible from within $\pm 0.01 \mathrm{~V}, e g, E_{h / 2}$ of the anodic wave of $\mathrm{Et}_{4} \mathrm{NBr}$ (Table 1), to several times that amount.

The reproducibility of the limiting current is fair for repeated runs on the same solution, but the concentration-dependence of the limiting current is rather variable, probably due to the inherent behaviour of a stationary solid electrode and to the effect of migration current arising from the absence of background elcctrolyte.

Plots of $\log \left[i /\left(i_{1}-i\right)\right] r s E$ for anodic waves of $\mathrm{Et}_{4} \mathrm{NBr}$ and $\mathrm{Et}_{4} \mathrm{NCl}$ are at most only partly linear; the linear portion of the anodic bromide wave has a slope of 0.053 . The calculated slope for a reversible 1 -e process at $-20^{\circ} \mathrm{C}$ is $0.050 \mathrm{~V}$. 


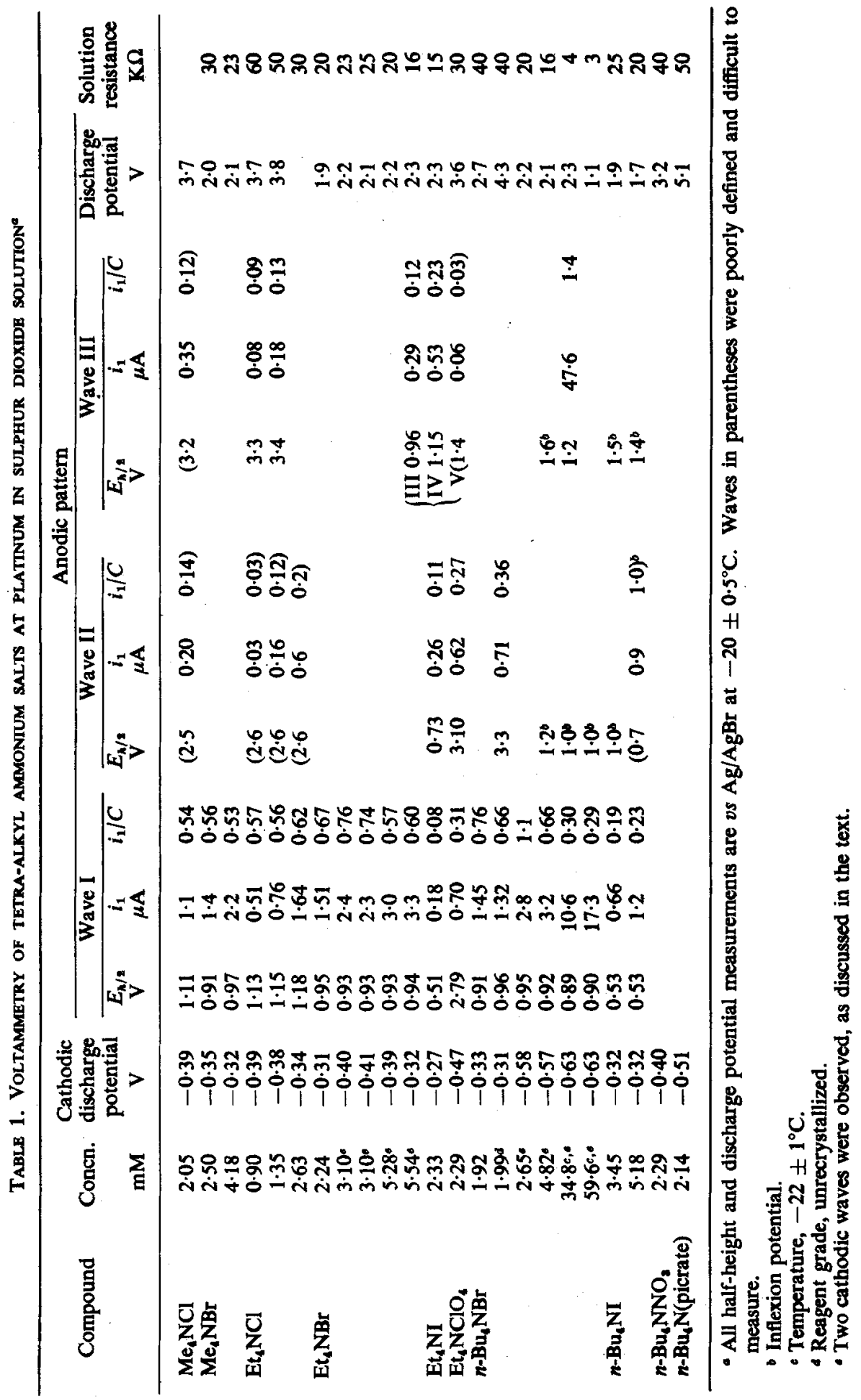


TABLE 2. Voltammetry OF VARIOUS SPECIES AND MIXTURES AT PLATINUM IN SULPHUR DIOXIDE SOLUTION

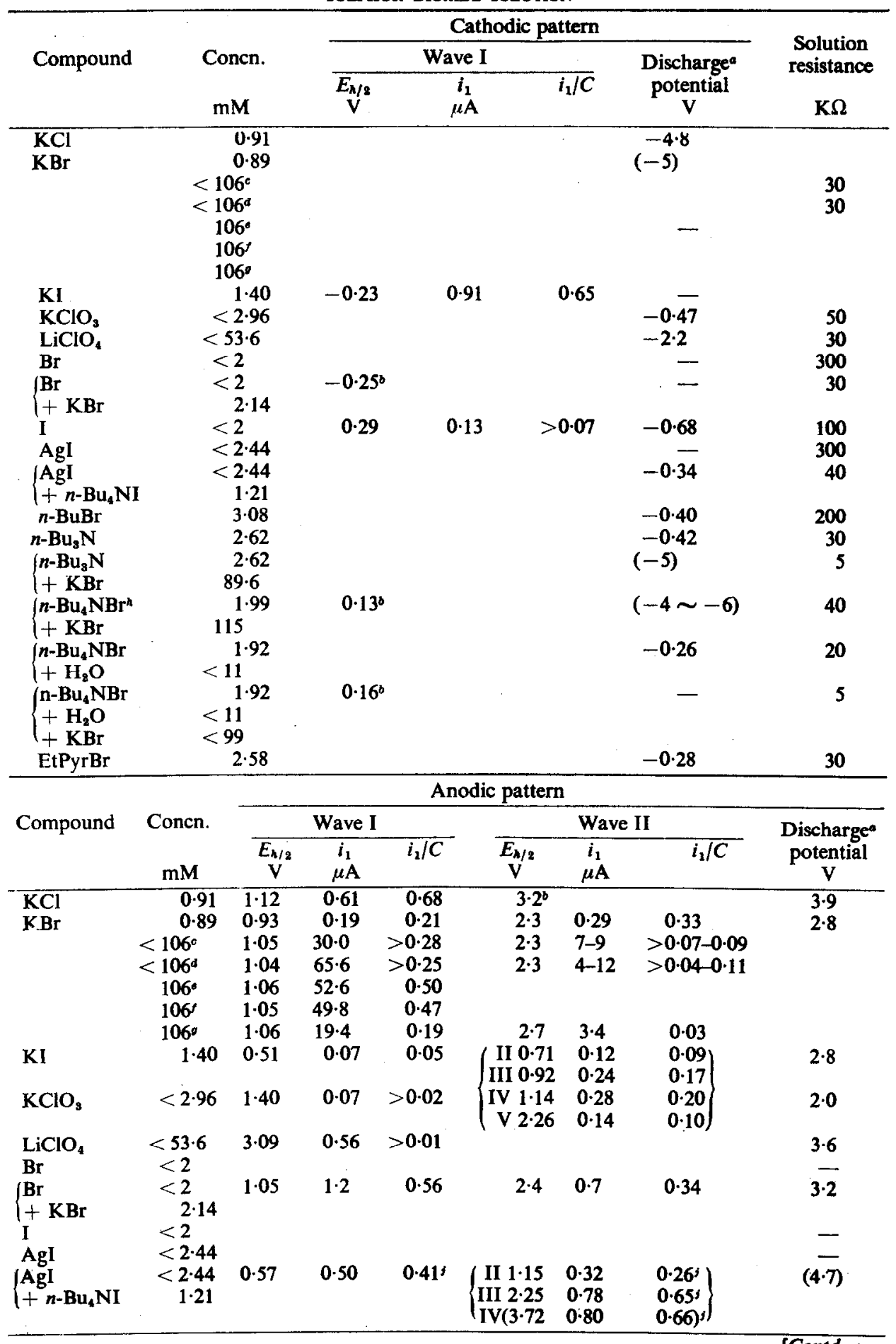


TABLE 2 (Contd.)

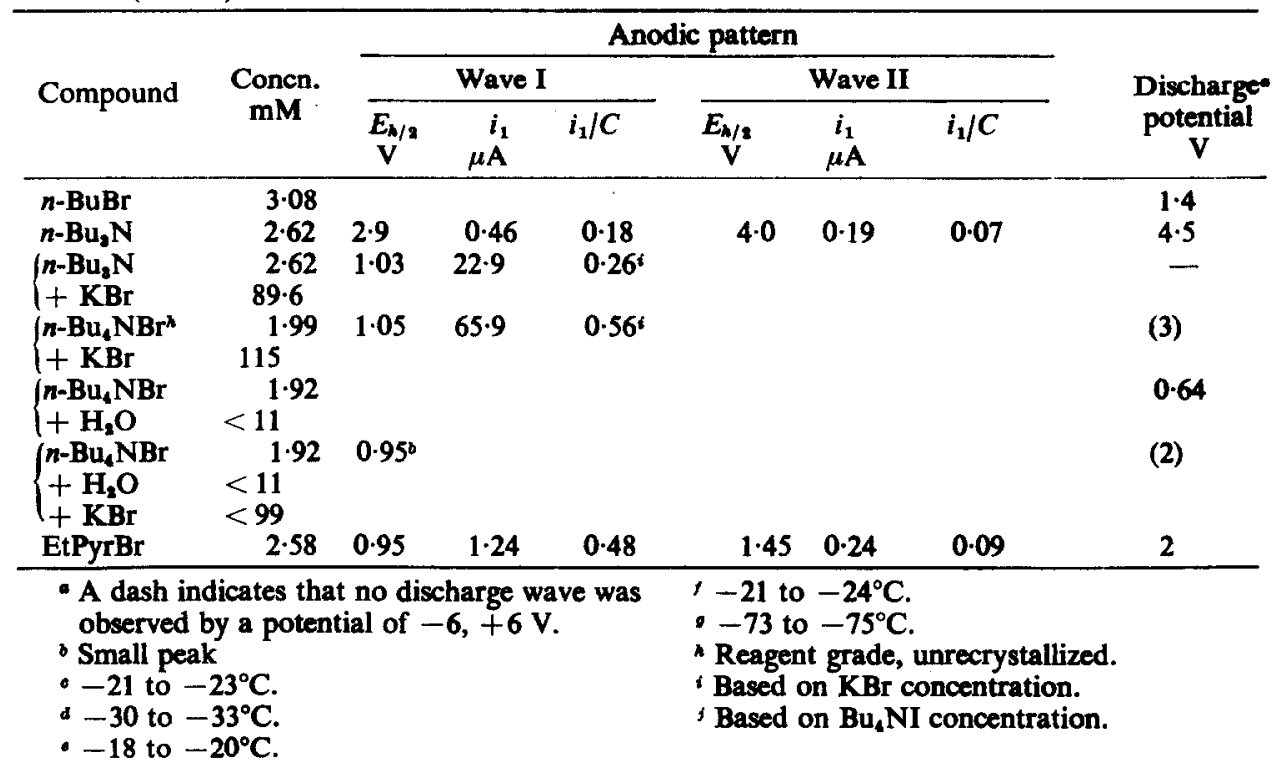

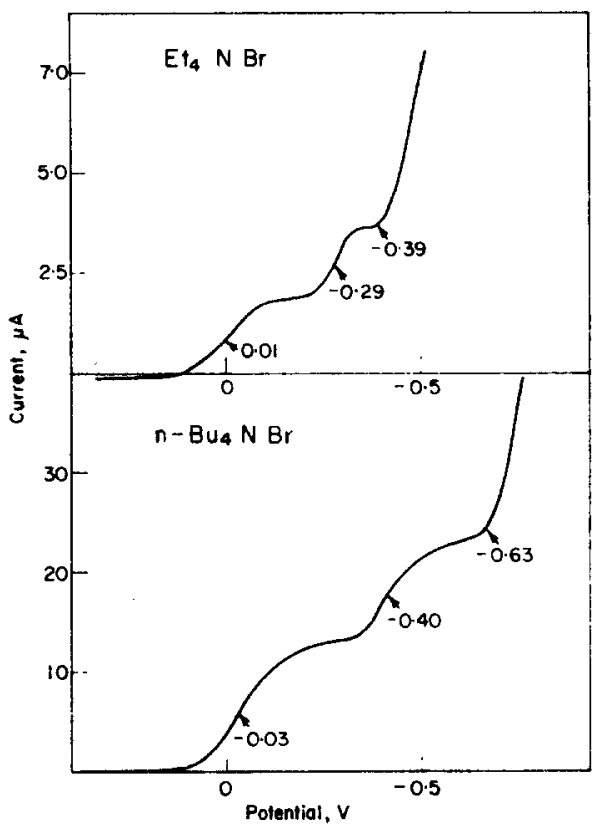

Fig. 2. Cathodic waves observed in solutions of $\mathrm{Et}_{4} \mathrm{NBr}(5.28 \mathrm{mM})$ and $n-\mathrm{Bu}, \mathrm{NBr}$

\section{Cathodic patterns}

(59.6 mM).

Of all the tetra-alkyl ammonium salts examined, only $\mathrm{Et}_{4} \mathrm{NBr}$ and $\mathrm{Bu}_{4} \mathrm{NBr}$ on a few occasions exhibited cathodic waves before discharge (Fig. 2). The two welldefined waves found in each case are not due to the usual impurities present in tetraalkyl ammonium salts, oxygen (air), water or sulphur trioxide, but are caused by some non-condensable gas or gases in the sulphur dioxide, which can be eliminted by boiling 
the liquid sulphur dioxide for about $30 \mathrm{~min}$ before charging it into the cell. The effect of the appearance of these cathodic waves on the cathodic discharge potential is discussed in the next section.

\section{Cathodic discharge potentials}

The cathodic discharge potentials of solutions of the tetra-alkyl ammonium salts examined are generally within the range $-0.3--0.6 \mathrm{~V}$, which is very much less negative than those observed in aqueous polarography at the dme. The fact that the discharge is due to the presence of the quaternary ammonium ion and not to the reduction of silver ion arising from dissolution of silver bromide from the reference electrode is indicated by the negative effect of adding silver iodide, which has the largest solubility in liquid sulphur dioxide $\left(0.68 \mathrm{mM} / 1000 \mathrm{~g}\right.$ of solvent at $\left.0^{\circ} \mathrm{C}\right)$ among silver halides. ${ }^{9}$

The discharge potentials for a given tetra-alkyl ammonium salt solution vary somewhat with concentration and considerably with the nature of the anion (Fig. 3). In the case of the bromides, where two cathodic waves were observed, the discharge potentials were more negative in the presence of these waves than in their absence.

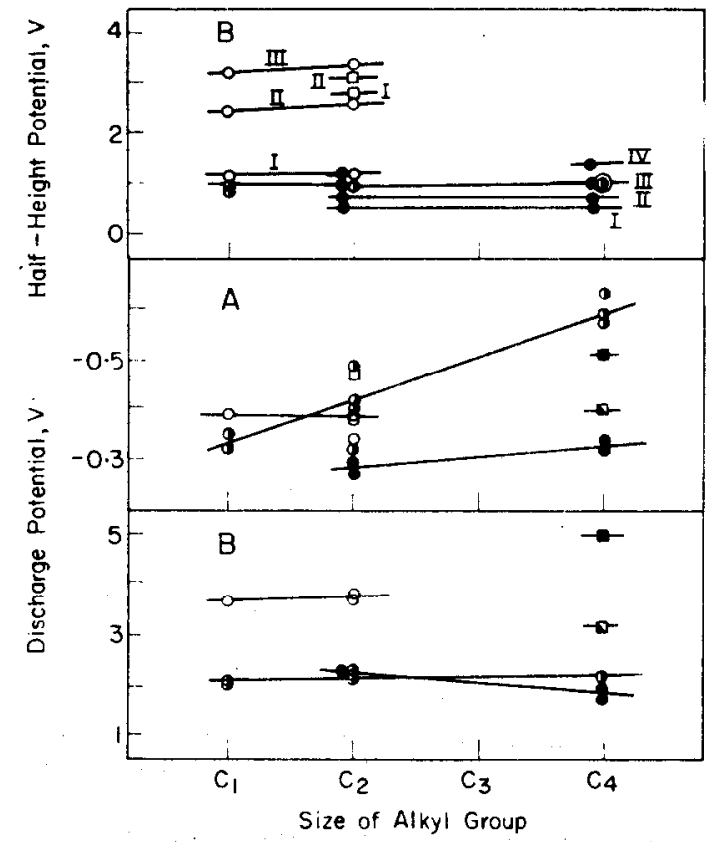

FIG. 3. Variation of half-height and discharge potentials for (A) cathodic waves and (B) anodic waves with size of the alkyl group in $\mathrm{R}_{\mathbf{4}} \mathrm{NX}$.

The anion, $\mathrm{X}$, is represented by open circles for $\mathrm{Cl}^{-}$, half-closed circles for $\mathrm{Br}^{-}$, closed circles for $\mathrm{I}^{-}$, rectangles for $\mathrm{ClO}_{4}^{-}$, half-closed rectangles for $\mathrm{NO}_{3}{ }_{3}$, and closed rectangles for picrate. The roman numbers represent the waves.

A nearly linear relationship between discharge potential and size of the alkyl group is observed for the bromides; the potentials used in Fig. 3 are for the case where the two cathodic waves appeared; use of the potentials obtained in their absence results in a more horizontal line. The relations for the iodides and chlorides are less clear. 
TABLe 3. SLOPES OF Discharge CURRENTS FOR SELECTED COMPOUNDS

\begin{tabular}{|c|c|c|c|c|}
\hline \multirow{2}{*}{ Compound } & \multirow{2}{*}{$\begin{array}{c}\text { Concn. } \\
\mathrm{mM}\end{array}$} & \multicolumn{2}{|c|}{$\begin{array}{l}\text { Slope of } \\
\text { discharge current } v s \text { voltage, } \mathrm{K} \Omega\end{array}$} & \multirow{2}{*}{$\begin{array}{c}\text { Solution } \\
\text { resistance } \\
\mathbf{K} \Omega\end{array}$} \\
\hline & & Cathodic & Anodic & \\
\hline $\begin{array}{l}\mathrm{Me}_{4} \mathrm{NCl} \\
\mathrm{Et}_{4} \mathrm{NBr} \\
n-\mathrm{Bu}_{4} \mathrm{NI} \\
\mathrm{Et}_{4} \mathrm{NClO} \\
1-\mathrm{EtPyrBr} \\
n-\mathrm{Bu}_{8} \mathrm{~N} \\
n-\mathrm{Bu}_{8} \mathrm{~N} \\
+\mathrm{KBr} \\
n-\mathrm{Bu} \mathbf{u}_{4} \mathrm{NBr}\end{array}$ & $\begin{array}{c}2.05 \\
3 \cdot 10 \\
3.45 \\
2.29 \\
2.58 \\
2.62 \\
2.62 \\
89.6 \\
1.99\end{array}$ & $\begin{array}{r}35 \\
25 \\
28 \\
18 \\
26 \\
356 \\
568 \\
\\
\\
135\end{array}$ & $\begin{array}{r}283 \\
176 \\
117 \\
99 \\
360 \\
1150\end{array}$ & $\begin{array}{r}40 \\
23 \\
25 \\
30 \\
30 \\
30 \\
5 \\
\\
40\end{array}$ \\
\hline$+\mathbf{K B r}$ & 115 & 130 & 84 & 40 \\
\hline
\end{tabular}

- Slope was calculated on the basis of Ohm's law.

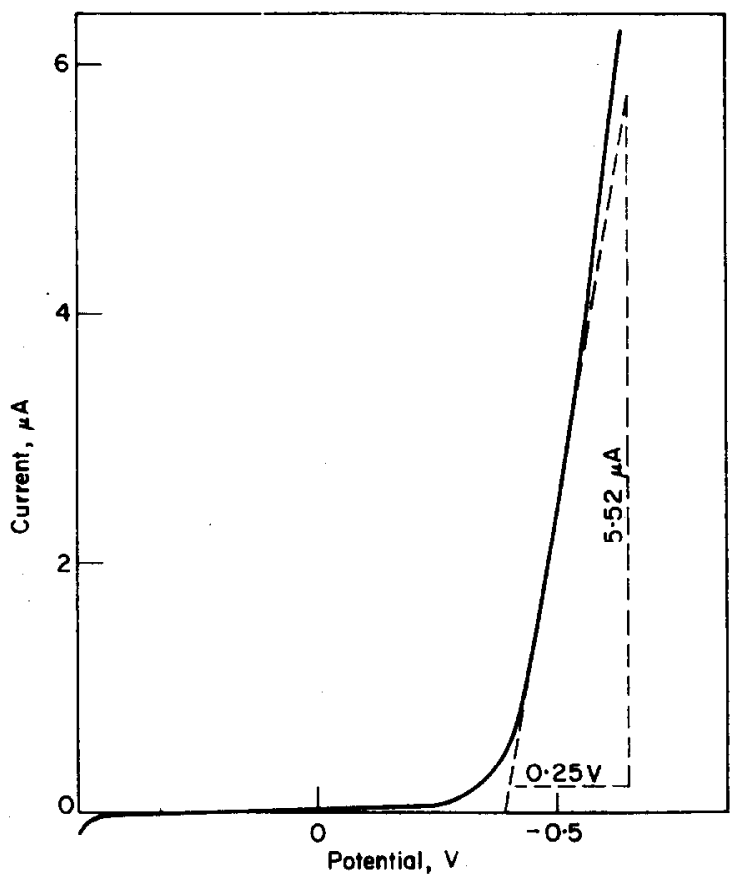

FIG. 4. Cathodic curve for tetra-n-butylammonium bromide, illustrating method of calculation of slope of discharge current, which in the example shown is $45 \mathrm{~K} \Omega$.

Since the potential applied to the cell equals the algebraic sum of the electrode potentials and the potential drop due to the passage of current through the cell resistance,

$$
E_{\text {appiled }}=E_{\mathrm{s}}-E_{\mathrm{c}}+i R_{\text {cell, }} \text {, }
$$

the appearance of a faradaic current due to electrolysis of a solution component will markedly increase the magnitude of the $I R$ drop. Where the latter is a major factor, the slope of the discharge portion of the wave pattern should be comparable to the cell resistance and independent of the nature of the species being electrolysed.

The magnitudes of the cathodic discharge currents of the tetra-alkyl ammonium salt solutions are much greater than those of the corresponding anodic discharge 
currents, as indicated by the slopes of the discharge currents (Table 3; method of calculation illustrated by Fig. 4).

The cathodic discharge current of ethylpyridinium bromide solution is comparable to those of the tetra-alkyl ammonium salts. Although the latter discharge currents are not completely linear, the values of the slopes, expressed in $\mathrm{K} \Omega$, coincide approximately with the solution resistance in each case, independent of the nature of the anion. Thus, the discharge currents appear to be nearly comparable to the so-called ohmic current caused by discharge of the polarographic background electrolyte.

On the other hand, the cathodic discharge currents of $n-\mathrm{Bu}_{3} \mathrm{~N}, n-\mathrm{Bu}_{3} \mathrm{~N}+\mathrm{KBr}$ and $n-\mathrm{Bu}_{4} \mathrm{NBr}+\mathrm{KBr}$, and all of the anodic discharge currents are much smaller, ie the calculated resistance values are much greater, than the cathodic discharge currents of the quaternary salts. This may well indicate a basic difference between the cathodic discharge reaction of the quaternary salts and all other cathodic and anodic discharge reactions.

The fact that the cathodic discharge currents of the quaternary ammonium salts are comparable to the ohmic current suggests the possible discharge reaction of $\mathbf{R}_{\mathbf{4}} \mathrm{N}^{+}$ions. However, in view of low potentials involved, it is also necessary to consider attack of the solvent, eg reduction of a salt-solvent complex, in which reaction the solvent is reduced and the salt is liberated, resulting in a possible recycling process whereby a relatively small amount of salt may result in the reduction of a large amount of solvent. The same consideration concerning electrolysis of the solvent may be applicable in the other cathodic and anodic discharge reactions, assuming that the ease of attack on the solvent depends on the nature of the ion concerned.

\section{Anodic pattern}

The anodic voltammograms of a tetra-alkyl ammonium halide and the corresponding alkali metal halide appear to be comparable in shape and in half-height potentials especially in the case of the iodides (typical polarograms are shown in Figs. 5-7).

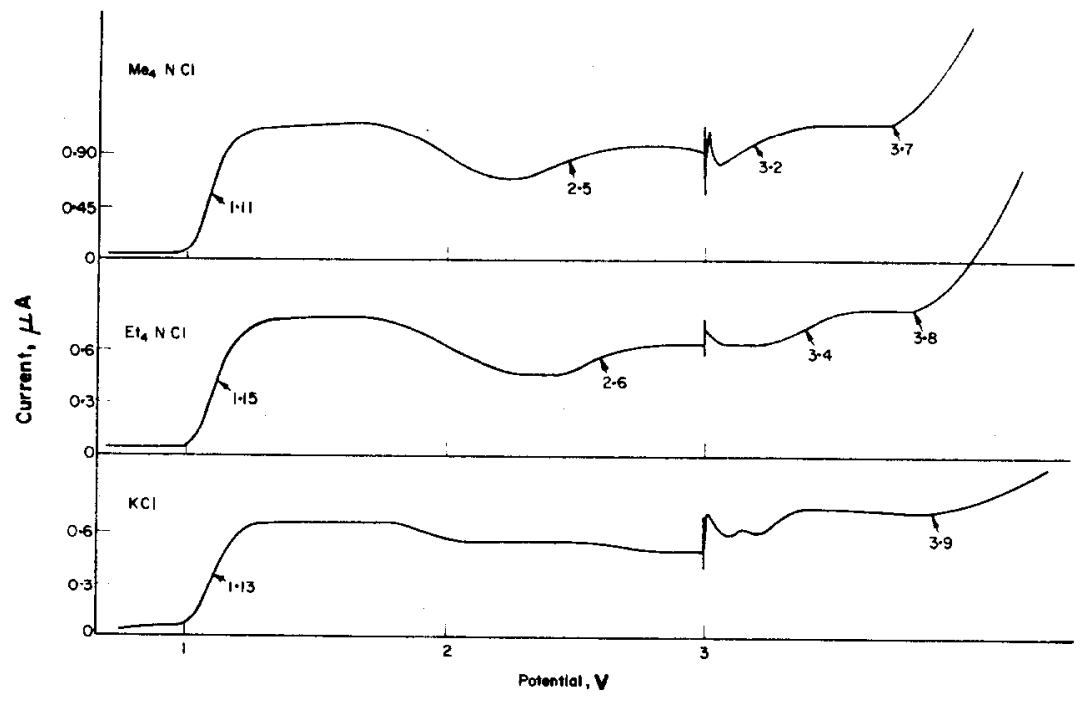

FIG. 5. Voltammograms of chlorides: anodic patterns for $\mathrm{Me}_{4} \mathrm{NCl}(2.05 \mathrm{mM}), \mathrm{Et}_{4} \mathrm{NCl}$

$(1.35 \mathrm{mM})$ and $\mathrm{KCl}(0.91 \mathrm{mM})$. 


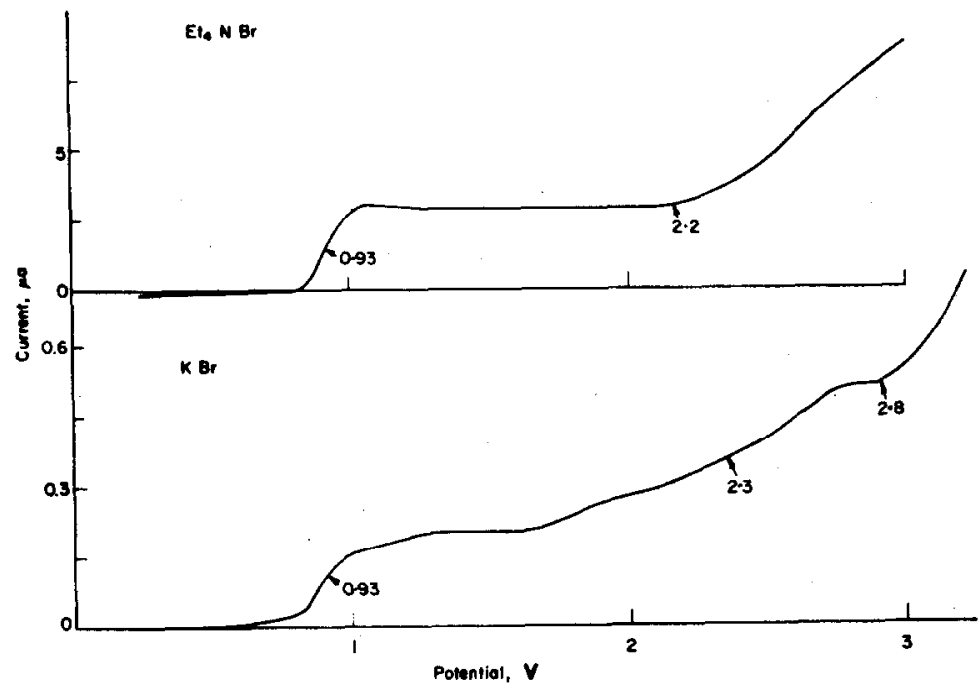

Fig. 6. Voltammograms of bromides: anodic patterns for $\mathrm{Et}_{4} \mathrm{NBr}(5.28 \mathrm{mM})$ and $\mathrm{KBr}$ $(0.89 \mathrm{mM})$.

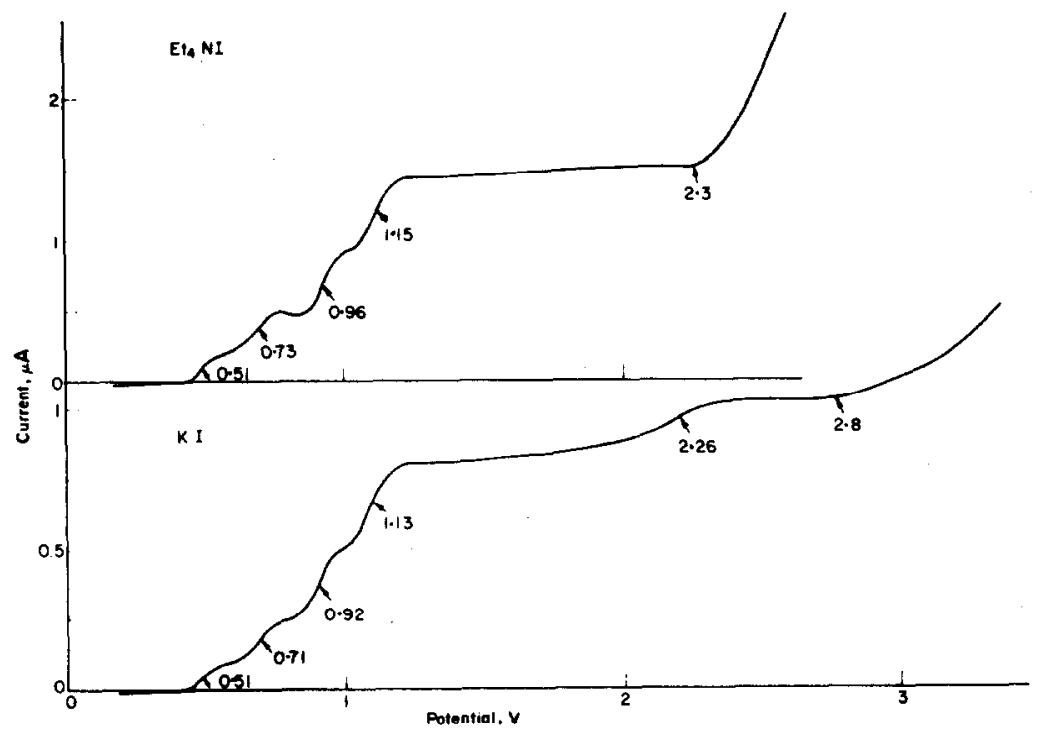

FIG. 7. Voltammograms of iodides: anodic patterns for $\mathrm{Et}_{4} \mathrm{NI}(2.33 \mathrm{mM})$ and $\mathrm{KI}$ $(1.40 \mathrm{mM})$.

The voltammograms of tetra-ethylammonium perchlorate and lithium perchlorate are also generally similar (Fig. 8).

The concentration dependence of the anodic limiting currents is somewhat variable, probably due to the effect of migration current arising from the absence of background electrolyte. However, the general pattern is clear. The magnitude of the current/ concentration ratio for the first anodic wave seems to increase with the size of the alkyl group, and to increase slightly in going from chloride to bromide but to decrease 


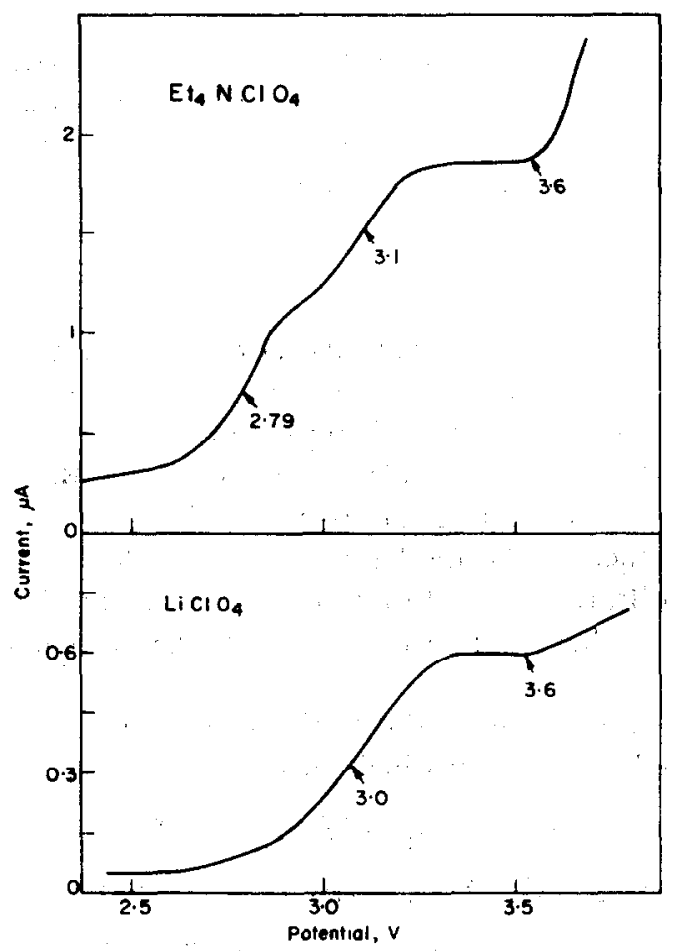

Fio. 8. Voltammograms of perchlorates: anodic patterns for $\mathrm{Et}_{4} \mathrm{NClO}_{4}(2 \cdot 29 \mathrm{mM})$ and $\mathrm{LiClO}_{4}(54 \mathrm{mM})$.

markedly in going from bromide to iodide. The value for perchlorate is between those for bromide or chloride and iodide.

The anodic voltammograms indicate the possible oxidation of each halide in multiple stages; three or more oxidation waves or inflexion potentials are observed, although the anodic polarograms of the bromide salts are rather simple in frequently showing only one wave.

The following oxidation stages have been described for each halogen in aqueous solution ${ }^{10,11}-1,+1,+3,+4,+5$ and +7 for chlorine; $-1,+1,(+3)$ and +5 for bromine; and $-1,+1,+3(+4),+5$ and +7 for iodine. The potential diagrams for the oxidation states in acid solution are given by Latimer. ${ }^{11}$

It would perhaps be possible to infer patterns for the multiple stage oxidation of each halide in liquid sulphur dioxide from comparison of the anodic polarograms of the halides in sulphur dioxide solution and the potential data for aqueous solution. Thus, the simplicity of the bromide polarograms appears comparable to that of the oxidation stages of bromide ion in aqueous solution. However, the waves observed have not been assigned to any given reaction, in spite of the suggestive nature of the wave patterns, since the latter also offer certain problems. For example, three waves at nearly the same potentials are given by $\mathrm{Me}_{4} \mathrm{NCl}$ and $\mathrm{Et}_{4} \mathrm{NCl}$ with the potentials of the second and third waves being comparable to those of the two waves of $\mathrm{Et}_{4} \mathrm{NClO}_{4}$ (Fig. 3).

Since the anodic waves of $\mathrm{Et}_{4} \mathrm{NClO}_{4}$ and $\mathrm{LiClO}_{4}$ are at much more positive potentials than the one wave of chlorate (Table 2) and do not exhibit the first chloride 
wave, they cannot be attributed to chlorate or chloride impurities. The waves appear to be due to attack of the solvent, such as a cyclic oxidation of a salt-solvent complex, or the formation of some intermediate, eg the perchlorate free radical.

Based on half-height potentials of the first waves and discharge potentials, the ease of oxidation of halide ions in liquid sulphur dioxide follows the order of iodide, bromide and chloride.

\section{Background electrolyte}

In the search for a satisfactory background electrolyte for use in liquid sulphur dioxide, potassium bromide was tried as such in cathodic runs on $\mathrm{Bu}_{4} \mathrm{NBr}$, because a $\mathrm{KBr}$ solution $(0.106 \mathrm{M})$ did not itself exhibit any cathodic wave or peak current before discharge. However, when $\mathrm{KBr}$ was added to a solution of $\mathrm{Bu}_{4} \mathrm{NBr}$, the normally observed discharge current of the latter disappeared (Table II).

Since the disappearance of the discharge current might be due to complexing between $\mathrm{Bu}_{4} \mathrm{NBr}$ and $\mathrm{KBr}$, the effect of the addition of $\mathrm{KBr}$ on the discharge current of tri- $n$-butyl amine was then examined; the discharge current of the latter also disappeared (Table 2).

The above phenomena may thus be due to the formation of complexes of the type described by Wickert and Jander, ${ }^{12}$ for which the following reactions may be assumed:

Similarly,

$$
\begin{aligned}
& 2 n-\mathrm{Bu}_{3} \mathrm{~N}+2 \mathrm{SO}_{2} \rightarrow\left[n-\mathrm{Bu}_{3} \mathrm{~N}\right]_{2} \cdot 2 \mathrm{SO}_{2}, \\
& {\left[n-\mathrm{Bu}_{3} \mathrm{~N}\right]_{2} \cdot 2 \mathrm{SO}_{2} } \rightarrow\left(\left[n-\mathrm{Bu}_{3} \mathrm{~N}\right]_{2} \mathrm{SO}\right) \mathrm{SO}_{3}, \\
&\left(\left[n-\mathrm{Bu}_{3} \mathrm{~N}\right]_{2} \mathrm{SO}\right) \mathrm{SO}_{3}+2 \mathrm{KBr} \rightarrow\left(\left[n-\mathrm{Bu}_{3} \mathrm{~N}\right]_{2} \mathrm{SO}\right) \mathrm{Br}_{2}+\mathrm{K}_{2} \mathrm{SO}_{3} .
\end{aligned}
$$

\section{CONCLUSIONS}

Although the theoretical and experimental difficulty of the absence of satisfactory background electrolytes still exists, it now appears possible to study satisfactorily the polarographic behaviour in liquid sulphur dioxide of, eg. halogen compounds or free radical systems, when using the present technique of the stationary disk platinum indicating microelectrode and automatic compensation of the $I R$ drop via a threeelectrode system.

Future investigation of the methodology of polarography in liquid sulphur dioxide, in addition to the search for suitable background electrolytes, should include study of the effects of agitation of the test solution by means of a rotated indicator electrode as well as the usefulness of the application of other electrochemical techniques, such as chronopotentiometry, cyclic voltammetry and controlled potential coulometry. In addition, the quantitative contribution of the migration current should be considered.

In the present study of the voltammetry of tetra-alkyl ammonium halides and related compounds in liquid sulphur dioxide, fairly good reproducibility of the polarograms was obtained and the features of the anodic and cathodic behaviour were characterized.

The anodic polarograms show three or more waves for chlorides and iodides, and 
relatively simple wave patterns for bromides, which may possibly be attributed to multiple-stage oxidation.

The cathodic discharge potentials, which are attributable to reduction of the quaternary species or to attack of the solvent, are much less negative than those of the tetra-alkyl ammonium ions in aqueous solution.

Acknowledgement-The authors thank the U.S. National Science Foundation, which helped support the work described.

\section{REFERENCES}

1. P. J. Elving, J. M. Markowitz and I. Rosenthal, J. Phys. Chem. 65, 680 (1961).

2. P. J. Elving and J. M. Markowitz, J. Phys. Chem. 65, 686 (1961).

3. P. J. Elving, E. Vianello and M. Spritzer, unpublished work.

4. K. CRUSE, Z. Elektrochem. 46, 571 (1940).

5. P. J. Elving and H. Shimojima, unpublished work.

6. R. G. Bates, Determination of pH. Wiley, New York (1964).

7. P. Arthur, P. A. Lewis, N. A. Lloyd and R. H. Vanderkam, Analyt. Chem. 33, 448 (1961).

8. P. Arthur and R. H. Vanderkam, Analyt. Chem. 33, 765 (1961).

9. G. JANDER, Die Chemie in Wasserähnlichen Lösungmitteln. Springer, Berlin (1949).

10. G. Charlot, Oxidation-Reduction Potentials. Pergamon Press, London (1958).

11. W. M. LATIMER, The Oxidation States of Elements and Their Potentials in Aqueous Solution. Prentice-Hall, New York (1952).

12. K. WICKERT and G. JANDER, Ber. 70, 251 (1937). 